\title{
Improvement of port operations efficiency of the Arctic Maritime Transport Route
}

\author{
Aleksey Vasilievich Abramov \\ Saint Petersburg State Marine \\ Technical University \\ Saint Petersburg, Russia \\ abr_ek@mail.ru
}

\author{
Michail Aleksandrovich Zagorodnikov \\ National Research Center "N. E. \\ Zhukovsky Institute" \\ Moscow, Russia \\ vm007@mail.ru
}

\begin{abstract}
Russian Federation Government Program "Transport System Development" includes different activities on technical maintenance of water routes and hydraulic structures, maritime traffic search-and-rescue aid, shipping navigation and surveying facilities for the Northern Sea Route lines. The aim of this work is studying year-round performance efficiency improvement of the Russian Arctic Maritime Transport Route (AMTR) including shore infrastructure which affects reducing port operations during transportation of cargo. In order to achieve this goal comparative analysis of implementation of investment projects for shore infrastructure development is presented in the article. There is an example of an innovative project for introduction of an automated loading facility. Based on the given data on activities for improvement of port operations efficiency and according to experts about $20 \%$ improvement is possible.
\end{abstract}

Keywords-transport route, Arctic Zone of Russia, industry, maritime transport, sea ports, infrastructure

\section{INTRODUCTION}

Russia faces an important task of developing the Arctic Zone and the Northern Sea Route and this problem should be solved based on the general principle of strategic planning: from the future to the present, and this principle fundamentally differs from the principle of forward planning: from the past to the future.

Let's define the mission and objectives of developing northern maritime transport infrastructure of Russia. Mission is achieving smooth activity of the Arctic Zone territories. Objective is providing year-round shipping traffic along the Northern Sea Route lines within the established time limits.

The aim of this work is to study year-round performance efficiency improvement of the Russian Arctic Maritime Transport Route (AMTR).

Sea transport is a very important sustaining means of many northern territories of the Russian Federation. Thanks to sea transportation which provides delivery of necessary products and removal of new outcomes of productive activity there exists year-round extraction, production and exportation of oil, nickel, cuprum, tin and many other natural resources.

The Russian Federation Government Program "Transport System Development" (subprogram "Marine and Inland Water Transport") includes different activities on technical maintenance of water routes and hydraulic structures, maritime traffic search-and-rescue aid, shipping navigation and surveying facilities for the Northern Sea Route lines.

According to the program it is planned to increase the volume of transportation along the Northern Sea Route up to $63.7 \mathrm{mln}$ tons by 2020 , the project also provides increasing the level of technical equipment capability of the Northern Sea Route lines up to $40.5 \%$. The program also provides activities on developing major sea ports including Arkhangelsk and Murmansk. [1].

Improvement of economical efficiency of transportation with simultaneous sharp increase in the volume of cargo transportation along the Norther Sea Route can be achieved only by simultaneous increase of cargo turnover and reduction of transportation unitary cost. [3, 6]

Quite a number of publications are devoted to prospects, objectives and problems of developing the maritime transportation system of the Northern Sea Route. A substantial contribution into in-depth study of this question was made by Federal State Unitary Enterprise "Krylov State Research Center", Public Company "Central Design Bureau Iceberg", Joint Stock Corporation "Shipbuilding and Ship repair Technology Center", CNIIMF, Russian Transport Academy, Admiral Makarov State University of Maritime and Inland Shipping, and others. Among different studies on the subject one could lay emphasis on works of the following scientists: A.A. Aleksashin, E.M. Apollonov, S.I. Bujanov, A.V. Istomin, Yu.F. Lukin, V.M. Pashin, V.N. Polovinkin, V.I.. Peresypkin, V.V. Ruksha, Tsoy L.G., etc.

Analysis and generalization of scientific works of foreign and native authors on the subject, despite their broad spectrum, shows that in scientific literature the problem of managing strategic planning of development of the Arctic Maritime Transport Route amid global competition has been underreported to this date.

\section{MATERIALS AND METHODS}

Dynamics of development of the Arctic Maritime Transport Route stated by decision documents can be achieved by providing distinct correlation between state strategic tasks and specific ship building tasks including validity of claims to marine facilities and optimization of their cost indicators.

Program-targeted goal planning may serve as a methodological basis for this correlation. 
The article is based on data of the Federal State Statistics Service, the Federal Agency of Subsurface Resources Management of the RF, the RF Ministry of Transportation, Rosatomflot, Public Company Sovcomflot, Rosmorport, Gecon Analyst Company.

\section{RESULTS}

The strategy of ship-building development up to 2020 and further [2] includes separate economical and technical indicator values for transport maritime objects of the Northern Sea Route (table 1):

TABLE I. PROJECTED CHANGES OF INDICATOR VALUES.

\begin{tabular}{|l|l|}
\hline Indicator value & Change \\
\hline $\begin{array}{l}\text { reduction of power consumption in the course } \\
\text { of maintenance }\end{array}$ & $10-15 \% ;$ \\
\hline reduction of weight characteristics & $10-15 \%$ \\
\hline improvement in icebreaking capability & $20-25 \%$ \\
\hline $\begin{array}{l}\text { improvement in economic efficiency of } \\
\text { transportation }\end{array}$ & by a factor of $1.2-1.4$ \\
\hline
\end{tabular}

Therefore we admit that the indicator value of transportation activities efficiency along the North Sea Route, “ЭП”, is equal to 1.4 .

The basic requirement of the projected dynamics of the transport system development is the indicator "Increase in the volume of cargo transportation along the Northern Sea Route up to $63.7 \mathrm{mln}$ tons by 2020 " stated in the Russian Federation Government Program "Transport System Development" [1].

Taking into account the target indicator - the volume of cargo transportation along the Northern Sea Route (Vгр) - it is suggested to take the following value as the indicator value of efficiency (Эп):

where:

$$
\text { Эп = Vгр / Сп (1), }
$$

$\mathrm{C}_{\Pi}$ is total expenses of ship-owners and the State (yearly total costs).

Thus:

$$
\text { C_ח = Vгр / Э_п }
$$

As the costs can be divided into costs of movement operations, $\mathrm{C}_{д в}$, and costs of port operations, $\mathrm{C}_{\mathrm{c} \text {, }}$, then:

$$
\text { Эп }=\text { Vгр / (Сдв+Сст) }
$$

Improvement of transportation efficiency and increase in the volume of cargo transportation are stated in the strategic plan of the Northern Sea Route development. Therefore, yearly costs of cargo transportation which correspond to the other preset parameters remain unknown.

Let us create a mathematic model of determining the specific quantity of costs which makes it possible to achieve the determined strategic goals.

$$
\mathrm{X}_{1} * \text { Эп }=\mathrm{X} 2 * \mathrm{~V} г \mathrm{p} / \mathrm{X} 3 *(\mathrm{Cдв}+\mathrm{Cc})
$$

where:

$\mathrm{X}_{1}$ - coefficient of change of transportation efficiency;

$\mathrm{X}_{2}$ - coefficient of change of cargo transportation volume; $\mathrm{X}_{3}$ - coefficient of change of yearly costs of cargo transportation

When coefficient values are equal to: $X_{1}=X_{2}=X_{3}=1.0$ it is stated that the condition of variables included into the mathematical model corresponds to their current value.

Let us apply to formula 4 coefficient values which correspond to strategic plans.

$\mathrm{X}_{1}=1.4$ (maximum value of planned increase in improvement of transportation along the Northern Sea Route efficiency);

60 mln tons (planned

volume of delivered cargo)

$$
\begin{aligned}
& \mathrm{X}_{2}=\mathrm{mln} \text { tons (current volume } \\
& \quad \text { of delivered cargo) }
\end{aligned}
$$

$\mathrm{X}_{3}=$ ?

$$
\mathrm{X} 3 *(\text { Сдв }+ \text { Сст })=15 * \text { Vгр } / 1,4 * \text { Эп }
$$

Wherefrom:

$$
\begin{aligned}
& \mathrm{X} 3=\frac{15 * \mathrm{~V} \text { гр }}{\mathbf{1 , 4} * Э \Pi *(\mathrm{Cдв}+\mathrm{Cст})}= \\
& =11 * \text { Vгр / Эп * (Сдв+Сст })
\end{aligned}
$$

Therefore, when the planned volume of delivered cargo increases up to $60 \mathrm{mln}$ tons and cargo transportation efficiency increases by a factor of 1.4 it is required to decrease yearly specific transportation expenses by $(11 / 15)$ nearly $25 \%$.

Where $\mathrm{X}_{1}=1.2$ (minimum value of planned increase in improvement of transportation along the Northern Sea Route efficiency):

$$
\mathrm{X} 3 *(\text { Сдв }+ \text { Сст })=\frac{15 * \text { Vгр }}{1,2 * \text { Эп }}
$$

$$
\begin{aligned}
& \text { Wherefrom: } \\
& \mathrm{X} 3=15 * \text { Vгр / 1,2* Эп * (Сдв + Сст })= \\
& =12,5 * \text { Vгр / Эп }(\text { Сдв + Сст })
\end{aligned}
$$

Therefore, wen the planned volume of delivered cargo increases up to $60 \mathrm{mln}$ tons and cargo transportation efficiency increases by a factor of 1.2 it is required to decrease yearly specific transportation expenses by $(12.5 / 15)$ nearly $17 \%$.

$$
\mathrm{C}_{\Pi}=(\text { Сдв }+ \text { Сст })
$$

Port operations cost is defined by being equipped with port infrastructure. Expert estimation has demonstrated that signification of movement operations within total costs is 0.7 and signification of port operations within total costs is 0.3 .

Let us consider implementation of the project of an automated loading terminal (ALT) as an example of increase in port operations efficiency. The terminal is meant for transmitting oil-products from a shore-based terminal to oil tankers with a capacity of $D=90$ thousand t in ice conditions of the Northern Sea Route (NSR):

- distance from a shore tank to the ALT located at the depth of $\approx 500 \mathrm{M}$ is about $5000 \mathrm{M}$; 
- speed of oil-products pumping according to project data is $\boldsymbol{V}=3000 \mathrm{~m}^{3} /$ hour (time spent on full filling of an oil tanker is $\approx 30$ hours);

- total pipeline length is $\approx 5500 \mathrm{~m}$, length of the pipe from the ALT to the buoy of the second type (with a swivel) is $\approx$ $450 \mathrm{~m}$;

- length of a flexible oil-pumping pipe (e.g. 601AA for oil H\B 10 bar, 601AA152686EE0 ALFAGOMMA152 6168 6.611015076030806 .82 ) with a locking device [9] for filling a tanker is $\approx 150 \mathrm{~m} \mathrm{[11].}$

The absence of an ALT makes it necessary to use shallowdraft (bunker) tankers for loading large-capacity marine transport vessels.

Expenditures on freight of bunker tankers (BT) and icebreaker ships when reloading from an offshore tank farm - terminal (OTF) to an Aframax tanker is presented in table 2.

The average time for a bunker tanker (BT) to pass a track section of $5 \mathrm{~km}$ with an average speed of $(6.4 \div 12.5$ knots $)$ 10 knots $(V c p=1.85 * 10=18.5 \mathrm{~km} /$ hour $)$ from an OTF to a high-capacity tanker, ice class, Aframax size, is equal to 0.27 hours. Therefore we can admit: $T n \approx 0.3$ hours.

Mooring of a bunker tanker to the oil terminal should be performed under the following conditions [7]:

- coming into the berth with extreme caution,

- in order to avoid impacting, rubbing, ship collision, pudding fenders should be used;

- the terminal berths should be equipped with properly functioning wooden or rubber fender guards.

The peculiarity of a tanker mooring to the terminal is that shipboard and shore pipelines must be joined: thus, wellcoordinated work of tow boats, shore and shipboard linehandling crews under the guidance of a pilot is required. Pipeline fitting is performed with the help of shore hosing devices.

Cargo operations in the berthing facility are connected with the danger of polluting the water area with oil-products in case of connecting hoses blowout, deck scupper spillover of freight. For that matter, oil basin fencing devices are applied in oil harbors.

The time spent on mooring-unmooring (preparation for filling) of each bunker tanker using a tow boat in the port, is equal to [8]: Twn $\approx 1.34$ hours.

The time spent on harbor mooring-unmooring of each bunker tanker with a high-capacity tanker is [8]: Tup $\approx 1.34$ hours.

The speed of pumping oil into a tanker with 10000-17000 deadweight is $V_{M m}=1200-2200 \mathrm{~m}^{3} /$ hour [13] (the average speed is $2000 \mathrm{~m}^{3} /$ hour, the time of filling a low-tonnage tanker is 5 hours, without preparatory works, therefore the full time of filling is approximately equal to: $T_{3} \approx 5$ hours)

The speed of pumping (offloading) oil from a lowtonnage tanker into a tanker, with deadweight 90000 by analogy is $T_{6} \approx 5$ hours.

Thus, the total time required for transportation and loading-unloading of 10000 tons of oil-products on each bunker tanker from an offshore terminal into a high-capacity tanker will be approximately equal to:

Тбз- - Tn + Tun + Tup $=0.3+5+5+1.34+1.34 \approx 17$ hours.
Taking into account time for the bunker tanker "return" trip (into the port) the full cycle is: $T u=17.3$ hours.

TABLE II. EXPENDITURES ON FREIGHT OF BT, AFRAMAX AND ICEBREAKER SHIPS

\begin{tabular}{|c|c|c|c|c|}
\hline $\begin{array}{l}\text { Expenditu } \\
\text { res indicator }\end{array}$ & $\begin{array}{l}\text { Freig } \\
\text { ht cost for } \\
1 \quad \text { BT, } \\
\text { rubles/da } \\
\text { y }\end{array}$ & $\begin{array}{l}\text { Freig } \\
\text { ht cost for } \\
1 \quad \text { BT, } \\
\$ \text { /day }\end{array}$ & 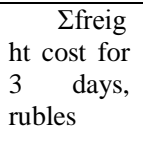 & 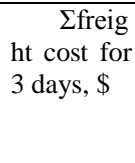 \\
\hline $\begin{array}{c}\text { Bunker } \\
\text { tankers freight }\end{array}$ & 359,784 & 5,700 & $3,238,060$ & 51,300 \\
\hline $\begin{array}{l}\text { Freight of } \\
\text { an icebreaker } \\
\text { ship for BT }\end{array}$ & $9,070,344$ & 143,740 & $27,211,032$ & 431,220 \\
\hline $\begin{array}{l}\text { Aframax } \\
\text { freight }\end{array}$ & $4,418,000$ & 70,000 & $13,255,200$ & 210,000 \\
\hline $\begin{array}{l}\text { Freight of } \\
\text { an icebreaker } \\
\text { ship } \\
\text { Aframax }\end{array}$ & $\begin{array}{l}13,700,00 \\
0\end{array}$ & 217,047 & $41,100,000$ & 651,141 \\
\hline Total & & & $84,804,292$ & $1,343,541$ \\
\hline
\end{tabular}

Expenditures on the ALT and an icebreaker ship when reloading from an OTF to an Aframax tanker within the period of 1.3 days (table 3 , providing that the time for matingseparating of a tanker and the ALT is 1 hour the time for loading will be $T A L T=30+1=31$ hours $\approx 1.3$ days):

TABLE III. EXPENDITURES ON FREIGHT OF BT, AFRAMAX AND ICEBREAKER SHIPS

\begin{tabular}{|c|c|c|c|c|}
\hline $\begin{array}{l}\text { Expenditu } \\
\text { res indicator }\end{array}$ & $\begin{array}{l}\text { Freig } \\
\text { ht cost for } \\
1 \quad \mathrm{pc} \text {, } \\
\text { rubles/da } \\
\mathrm{y}\end{array}$ & $\begin{array}{l}\text { Freig } \\
\text { ht cost for } \\
1 \quad \text { pc, } \\
\$ / \text { day }\end{array}$ & $\begin{array}{l}\quad \Sigma \text { freig } \\
\text { ht cost for } \\
1.3 \text { days, } \\
\text { rubles }\end{array}$ & $\begin{array}{r}\Sigma \text { freig } \\
\text { ht cost for } \\
1.3 \text { days, } \$\end{array}$ \\
\hline $\begin{array}{l}\text { Aframax } \\
\text { freight }\end{array}$ & $4,418,000$ & 70,000 & $5,743,400$ & 90,992 \\
\hline $\begin{array}{lr} & \text { Freight of } \\
\text { an icebreaker } \\
\text { ship } \\
\text { Aframax }\end{array}$ & $\begin{array}{l}13,700,00 \\
0\end{array}$ & 217,047 & $17,810,000$ & 282,161 \\
\hline Total & & & $23,553,000$ & 373,153 \\
\hline
\end{tabular}

So, expenditures for loading one Aframax tanker using a BT are: 84,804,292 rubles and using an ALT: 23,553,000 rubles. Therefore, difference is (economy of using an ALT): $R \Sigma=61,251,292$ rubles $\approx 970,395 \$$.

Expenditures on creating the ALT infrastructure are $C_{\ni} \approx$ $432.40 \mathrm{mln}$ rubles.

Let's divide the ALT implementation costs by the cost saving total:

$$
Э \phi=432,400,000 / 61,251,292=7.06 .
$$

Thus, we can make a conclusion that the company using an ALT will get profit starting from loading the eighth Aframax tanker.

\section{DISCUSSION}

First of all, efficiency of port operations depends on such factors as availability of a port, its infrastructure, the necessity to provide unloading equipment, unloading speed, weather conditions, the necessity to involve additional supply vessels, and also on the nature of cargo: volume-weight characteristics (bulk cargo (crushed stone), measurement cargo (cabins, tanks), stowing dimensions (cargo within loading gauge/oversized cargo), hazard class 
(hazardous/nonhazardous cargo), cargo requiring special transport conditions (a plate).

The State and private enterprises conduct significant efforts for improving efficiency of port operations by constructing new and modern northern sea ports and technical re-equipment of operating ports. [4, 5, 12, 13]

The following investment projects which are being implemented in the Arctic Zone of Russia can be specified as an example (Table 4.).

TABLE IV. INVESTMENT PROJECTS IN THE AZR

\begin{tabular}{|c|c|c|c|c|}
\hline Project Name & $\begin{array}{l}\text { Project } \\
\text { Capacity }\end{array}$ & $\begin{array}{l}\text { Cargo } \\
\text { classifica } \\
\text { tion }\end{array}$ & $\begin{array}{l}\text { Implementa } \\
\text { tion cost }\end{array}$ & $\begin{array}{l}\text { Impleme } \\
\text { ntation } \\
\text { timeline }\end{array}$ \\
\hline $\begin{array}{l}\text { Sabetta sea port } \\
\text { construction }\end{array}$ & $\begin{array}{l}17.6 \quad \mathrm{mln} \\
\text { tons. }\end{array}$ & $\begin{array}{l}\text { Condense } \\
\text { d natural } \\
\text { gas } \\
(\mathrm{CNG}), \\
\text { gas } \\
\text { condensa } \\
\text { te }\end{array}$ & $\begin{array}{l}\text { Sabetta } \\
\text { port: } \\
102.9 \text { bln } \\
\text { rub., } \\
\text { including: } \\
71.3 \text { bln } \\
\text { rub. } \\
\text { (federal } \\
\text { budget } \\
\text { resources). } \\
31.6 \quad \text { bln } \\
\text { rub. } \\
\text { (investor } \\
\text { resources) }\end{array}$ & $\begin{array}{l}2012- \\
2018\end{array}$ \\
\hline 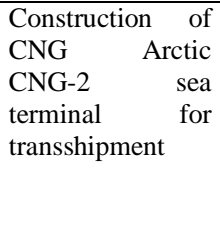 & $\begin{array}{l}\text { Projected } \\
\text { volume of } \\
\text { transshipme } \\
\text { nt of CNG- } \\
16.5 \quad \mathrm{mln} \\
\text { tons. }\end{array}$ & $\begin{array}{l}\text { Condense } \\
\text { d natural } \\
\text { gas } \\
\text { (CNG), } \\
\text { gas } \\
\text { condensa } \\
\text { te }\end{array}$ & $\begin{array}{l}\text { About } 70 \\
\text { bln rub. }\end{array}$ & $\begin{array}{l}2016- \\
2025 \\
\text { Phase } 1 \\
\text { start is } \\
\text { possible } \\
\text { in 2022- } \\
2023\end{array}$ \\
\hline $\begin{array}{l}\text { Construction of a } \\
\text { terminal for oil } \\
\text { transshipment } \\
\text { from the Newport } \\
\text { facility }\end{array}$ & $\begin{array}{l}8.5 \quad \mathrm{mln} \\
\text { tons. }\end{array}$ & oil & $\begin{array}{l}10.9 \text { bln } \\
\text { rub. (at the } \\
\text { investor's } \\
\text { own } \\
\text { expense) }\end{array}$ & $\begin{array}{l}2013- \\
2016\end{array}$ \\
\hline \begin{tabular}{l}
\multicolumn{2}{l}{ Reconstruction } \\
of port \\
infrastructure \\
objects of the \\
second cargo \\
district \\
Murmansk in \\
port
\end{tabular} & $2 \mathrm{mln}$ tons & $\begin{array}{l}\text { Bulk } \\
\text { cargo ore } \\
\text { mineral, } \\
\text { imported } \\
\text { alumina }\end{array}$ & - & $\begin{array}{l}2013- \\
2017\end{array}$ \\
\hline \begin{tabular}{lr}
\multicolumn{3}{l}{ Reconstruction } \\
of the & second \\
cargo & district \\
objects & in \\
Murmansk & sea \\
port & \\
\end{tabular} & $3.7 \mathrm{mln}$ tons & coal & - & $\begin{array}{l}2014- \\
2017\end{array}$ \\
\hline $\begin{array}{l}\text { Reconstruction of } \\
\text { Naryan-Mar sea } \\
\text { port. }\end{array}$ & $\begin{array}{l}\text { port cargo } \\
\text { turnover } \\
\text { increase by } \\
350 \\
\text { thousand } \\
\text { tons by } \\
2020\end{array}$ & $\begin{array}{l}\text { wood, } \\
\text { coal, } \\
\text { mineral } \\
\text { raw } \\
\text { materials, } \\
\text { container } \\
\text { s, general } \\
\text { cargo }\end{array}$ & 3.7 bln rub. & $\begin{array}{l}\text { Engineeri } \\
\text { ng design } \\
-2018 \text {. } \\
\text { Reconstr } \\
\text { uction - } \\
\text { until } \\
2019 \text { - } \\
2020\end{array}$ \\
\hline $\begin{array}{l}\text { Construction of a } \\
\text { multi-purpose and } \\
\text { special-purpose } \\
\text { transhipping } \\
\text { complex in Indiga } \\
\text { port }\end{array}$ & $\begin{array}{l}\text { Up to } 5 \mathrm{mln} \\
\text { tons } \\
\text { implementi } \\
\text { ng Pechora } \\
\text { CNG } \\
\text { project }\end{array}$ & $\begin{array}{l}\text { CNG, oil, } \\
\text { oil- } \\
\text { product. } \\
\text { supply } \\
\text { cargo. } \\
\text { - can be } \\
\text { used as a } \\
\text { transport } \\
\text { hub of }\end{array}$ & $\begin{array}{l}1 \text { stage }- \\
353 \quad \mathrm{mln} \\
\text { rub. }\end{array}$ & $\begin{array}{l}\text { Schedule } \\
\text { d - } 2025\end{array}$ \\
\hline
\end{tabular}

\begin{tabular}{|c|c|c|c|c|}
\hline & & $\begin{array}{l}\text { Pechora } \\
\text { CNG } \\
\text { project } \\
\text { (Rosneft/ } \\
\text { Allte) }\end{array}$ & & \\
\hline $\begin{array}{l}\text { Construction of } \\
\text { an oil terminal on } \\
\text { Tanalau Cape }\end{array}$ & $\begin{array}{l}\text { oil terminal } \\
\text { capacity } 5 \\
\text { mln tons. } \\
\text { (up to } 7.3 \\
\text { by 2030) }\end{array}$ & Oil & 5.8 bln rub. & by 2025 \\
\hline $\begin{array}{l}\text { Construction of a } \\
\text { deep water area in } \\
\text { Arkhangelsk sea } \\
\text { port }\end{array}$ & $\begin{array}{l}\text { deep water } \\
\text { area with } \\
\text { the total } \\
\text { cargo } \\
\text { turnover of } \\
20 \text { mln tons } \\
\text { per year. } \\
\text { (according } \\
\text { to } \\
\text { optimistic } \\
\text { declared } \\
\text { projections } \\
\text { - } 37.5 \text { mln } \\
\text { t./year, } \\
\text { confirmed } \\
\text { basis - } 10 \\
\text { mln t.) }\end{array}$ & $\begin{array}{l}\text { Timber, } \\
\text { cellulose, } \\
\text { coal, } \\
\text { equipmen } \\
\text { t, metals, } \\
\text { bulk } \\
\text { cargo, } \\
\text { oil- } \\
\text { products, } \\
\text { industrial } \\
\text { and food } \\
\text { products }\end{array}$ & $\begin{array}{l}\text { The } \\
\text { investment } \\
\text { volume is } \\
\text { being } \\
\text { determined } \\
\text { with a } \\
\text { potential } \\
\text { investor, } \\
\text { Poly } \\
\text { Internationa } \\
\text { l }\end{array}$ & $\begin{array}{l}\text { An } \\
\text { agreemen } \\
\text { t on joint } \\
\text { implemen } \\
\text { tation of } \\
\text { the } \\
\text { project } \\
\text { with Poly } \\
\text { Internatio } \\
\text { nal } \\
\text { Holding } \\
\text { Co.,Ltd } \\
\text { has been } \\
\text { conclude } \\
\text { d. (China) } \\
2016 .\end{array}$ \\
\hline $\begin{array}{l}\text { Construction of a } \\
\text { coal terminal in } \\
\text { Beringovsky sea } \\
\text { port } \\
\text { (Bay of Arinai) }\end{array}$ & $\begin{array}{l}\text { a coal } \\
\text { terminal } \\
\text { with a } \\
\text { capacity of } \\
10 \text { mln tons } \\
\text { per year }\end{array}$ & coal & 5 bln rub. & $\begin{array}{l}2016- \\
2019\end{array}$ \\
\hline
\end{tabular}

Except construction and modernization of ports and port equipment actions are being carried out on introducing technical and organizational measures, e.g. such as reducing mooring-hosing operations, increasing unloading productivity, reducing the time for paperwork, reducing minimum time for "weather slots" used by transport vessels, etc. [10]

Based on the given data on activities for improvement of port operations efficiency and according to experts about $20 \%$ improvement is possible, that is $I Э c=1.2$.

\section{CONCLUSION}

1. The State has evolved a strategic plan for developing the Arctic Zone of Russia and the Arctic Maritime Transport Route and turning tramp shipping into regular year-round shipping.

2. Taking into account the target indicator - the volume of cargo transportation along the Arctic Maritime Transport Route per year - it is suggested to take the ratio between cargo turnover and yearly total costs as the indicator value of transportation efficiency.

3. The efficiency of cargo transportation along the NSR depends on the total volume of transported cargo and total expenses of ship-owners and the State taking into account tariff rate for ice channeling. 
4. Transport costs are composed of movement and port operations costs.

5. Based on the given data on activities for improvement of port operations efficiency and according to experts about $20 \%$ improvement is possible.

\section{REFERENCES}

[1] State Program of the Russian Federation "Development of the Transport System" (approved by the Russian Federation Government Decree of April 15, 2014, No. 319).

[2] Shipbuilding industry development strategy up to 2020 and further (approved by the ministerial Decree of the Russian Federation Ministry of Industry and Energy of September 6, 2007, No. 354).

[3] A.V. Abramov, M.Yu. Alekhin Methodological principles of support of including an extra-functionality element into the transport system. Economics and Enterprise, No. 7, 2017

[4] A.V. Abramov, M.A. Zagorodnikov Prospects of innovation development of the Russian Arctic Zone. Transport routes. St.Petersburg State Maritime Technical University, 2017. ISBN 978-588303-564-6

[5] M.A. Zagorodnikov, The problems of developing sea infrastructure of the Russian Arctic Zone: RNPK materials "Investments economy and financial consulting". - SPb.: Publishing house of St. Petersburg State Maritime Technical University, 2015.

[6] M.A. Zagorodnikov, I.M. Kalinin New prospects of the NSR development // Economic sciences. 2016. No. 2.
[7] Sea site. [Electronic source]. - Available at: URL: http://seamansea.ru/tankera/601- shvartovnye-operacii-tankera.html.

[8] Technological design standards for sea ports. RD 31.3.05-97. [Electronic source]. $\quad$ - Available at: URL:http://www.infosait.ru/norma_doc/8/8953/index.htm

[9] Technological design standards for oil product suppliers (oil delivery terminals), Departmental Norms of Production Engineering 5-95. [Electronic source]. - Available at: URL:http://www.complexdoc.ru/ntdpdf/483330/normy_tekhnologich eskogo_proektirovaniya_predpriyatii_po_obespecheniyu_neft.pdf

[10] V.I. Peresypkin The Arctic sea transport system is of great importance. [Electronic source] - URL: http://www.arcticinfo.ru/ExpertOpinion/Page/the-arctic-marine-transportation-systemis-essential

[11] The site of Polistirolbeton-SPb company.[Electronic source]. Available at: URL: http://www.polistirolbeton.spb.ru/; http://pbloki.ru/price.

[12] Kikkas, K., Romashkina, E. Potential Opportunities for the Arctic Transport Space (2018) 180 (1), 012016.

[13] A.Yu. Smirnov, A.V. Abramov Elaboration of the strategy of shipbuilding industry development in the context of digital economy. Research and practice conference "Digital transformation of economy and industry" (INPROM-2019) p. 174-179

[14] Vessel-hour rates of marine vessels loading-unloading. Technological design standards for oil product suppliers (oil delivery terminals), Departmental Norms of Production Engineering 5-95. Appendix 4. [Electronic source]. - Available at: URL: http://www.complexdoc.ru/ntdpdf/483330/normy_tekhnologicheskog o_proektirovaniya_predpriyatii_po_obespecheniyu_neft.pdf 